\title{
Regulation of opioid receptor signalling: Implications for the development of analgesic tolerance
}

\author{
Karim Nagi ${ }^{1,3}$ and Graciela Piñeyro 1,2,3*
}

\begin{abstract}
Opiate drugs are the most effective analgesics available but their clinical use is restricted by severe side effects. Some of these undesired actions appear after repeated administration and are related to adaptive changes directed at counteracting the consequences of sustained opioid receptor activation. Here we will discuss adaptations that contribute to the development of tolerance. The focus of the first part of the review is set on molecular mechanisms involved in the regulation of opioid receptor signalling in heterologous expression systems and neurons. In the second part we assess how adaptations that take place in vivo may contribute to analgesic tolerance developed during repeated opioid administration.
\end{abstract}

\section{Introduction}

Opiates are among the most effective analgesics known but their clinical use is limited by severe side effects. Some of these undesired actions including tolerance, dependence and abuse usually appear after repeated opioid administration, and have been linked to adaptations that take place in order to counteract prolonged opioid receptor activation $[1,2]$. Adaptive changes have been described at different organizational levels within the central nervous system, ranging from receptor and cellular alterations to functional modifications of different neuronal networks $[3,4]$. Regulation that occurs at the receptor level results in the progressive waning of signalling efficacy and is known as desensitization. Mechanisms of opioid receptor desensitization were initially characterized in immortalized cell lines [5] but more recent studies have extended observations to cultured neurons [6-8] and animal models [9-12]. Here we will review these findings with special focus on recent efforts to understand how regulation of receptor signalling may contribute to analgesic tolerance developed during repeated opioid administration.

\footnotetext{
* Correspondence: graciela.pineyro.filpo@umontreal.ca

'Département de Pharmacologie, Faculté de Médecine, Université de

Montréal, Canada

Full list of author information is available at the end of the article
}

\section{Opioid receptor regulation in heterologous expression systems}

Opioid receptor desensitization and endocytosis

Studies in immortalized cell lines have shown that like for many other G protein-coupled receptors (GPCRs), opioid receptor activation involves a series of conformational changes $[13,14]$ that trigger signalling and regulation. Regulatory steps usually start with phosphorylation of the receptor $[15,16]$ followed by $\beta$ arrestin recruitment $[17,18]$ and disruption of receptor signaling via G-protein coupled effectors $[19,20]$. In addition, since arrestins bind to the coat structure of clathrin-coated pits $[21,22]$ a great majority of ligands that promote functional desensitization also enhance sequestration. The frequent association of these two processes was initially taken as an indication that opioid receptor internalization and desensitization were causally linked [23,24], an interpretation that was reinforced by studies showing that morphine failed to induce both, internalization $[25,26]$ and desensitization $[27,28]$. Moreover, given that morphine induces more analgesic tolerance than agonists capable of triggering a full regulatory response [29-31], its high potential for tolerance was initially considered as the consequence of cellular adaptations to counteract sustained signaling by receptors that were unable to desensitize or internalize $[23,25,27]$. However, morphine's failure to trigger regulation of receptor signaling cannot be 
extended to all systems since several reports have shown that this drug causes $\beta$ arrestine recruitment, desensitization and endocytosis of mu (MORs) [32-35] and delta (DORs) [35,36] opioid receptors. Moreover, animal studies have confirmed that receptor regulation is essential for morphine tolerance to develop since transgenic mice lacking $\beta$ arrestin 2 display enhanced, longer lasting analgesic responses to the drug $[37,38]$. Based on these observations, the mechanism of morphine tolerance was reconsidered and the contribution of endocytosis re-evaluated. This alternative hypothesis proposes $\beta$ arrestin-driven receptor-G protein uncoupling (desensitization) as the mechanism responsible for the loss of morphine's analgesic action, which is in turn exacerbated by receptor failure to internalize and undergo resensitization $[38,39]$. However, this mechanism cannot be generalized to agonists that induce internalization or even to other opioid ligands that like morphine fail to do so. In particular, homologous desensitization does not account for tolerance induced by AR-M1000390, a low internalizing DOR agonist [40] whose repeated administration induces tolerance without modifying receptor ability to activate the $\mathrm{G}$ protein [12]. Moreover, internalization per se warrants neither resensitization nor absence of tolerance. For example although SNC-80 produces rapid internalization of DORs [41], its systemic administration induces long lasting analgesic tolerance after a single administration [11]. MOR activation by efficiently internalizing ligands is also associated with progressive loss of analgesic efficacy, although unlike SNC-80, MOR agonists require repeated administration for tolerance to develop [42].

\section{Post-endocytic sorting of opioid receptors}

Functional consequences of receptor internalization cannot be fully understood without considering what happens after sequestration. Hence, if internalization is associated to receptor recycling, the process allows to restore functional receptors to the membrane $[43,44]$. Both MORs [39] and DORs $[41,45,46]$ have been shown to undergo recycling that contributes to their functional resensitization. In contrast, if the receptor is preferentially directed towards the lysosomal compartment, internalization leads to prolonged desensitization due to its proteolytic degradation $[47,48]$.

Factors responsible for sorting opioid receptors to these alternative pathways are multiple, and some are specific to each receptor subtype. An important determinant of lysosomal sorting is ubiquitination [49] and both DORs and MORs have been shown to become ubiquitinated and degraded after stimulation. However, while DORs are ubiquitinated within minutes of activation $[48,50]$ MORs require various hours of stimulation
[51]. On the other hand, despite their rapid ubiquitination, DORs are not immediately degraded but may remain withheld in the endosomal compartment [52] for periods that may last as long as four hours of agonist exposure $[11,53]$. The discrepancy in the time required to undergo ubiquitination and degradation is consistent with the fact that DOR sorting towards the degradation path is not dependent upon ubiquitin addition $[48,54]$. Instead, their trafficking to the late endosomal compartment relies, at least in part, upon interaction with sorting proteins of the GASP (G protein coupled receptor associated sorting protein) family $[47,54,55]$. MORs also bind GASPs, but the low affinity of this interaction seems to account for their lower tendency to undergo lysosomal targeting and degradation as compared to DORs $[47,55]$. In addition, a primary sequence within the C-terminal domain of some MOR isoforms facilitates their active targeting towards the recycling pathway [56]. Yet this is not the only determinant of MOR recycling since isoforms lacking the sorting sequence may also be sent back to the membrane after internalization $[57,58]$. Indeed, MORs are also known to constitutively interact with neuronal membrane glycoprotein M6a, which accelerates their recycling after internalization [59]. In addition, MOR and DOR recycling may be dynamically regulated through receptor phosphorylation $[46,60]$ and interactions with $\beta$ arrestin1 and $\beta$ arrestin2 [61]. See Figure 1

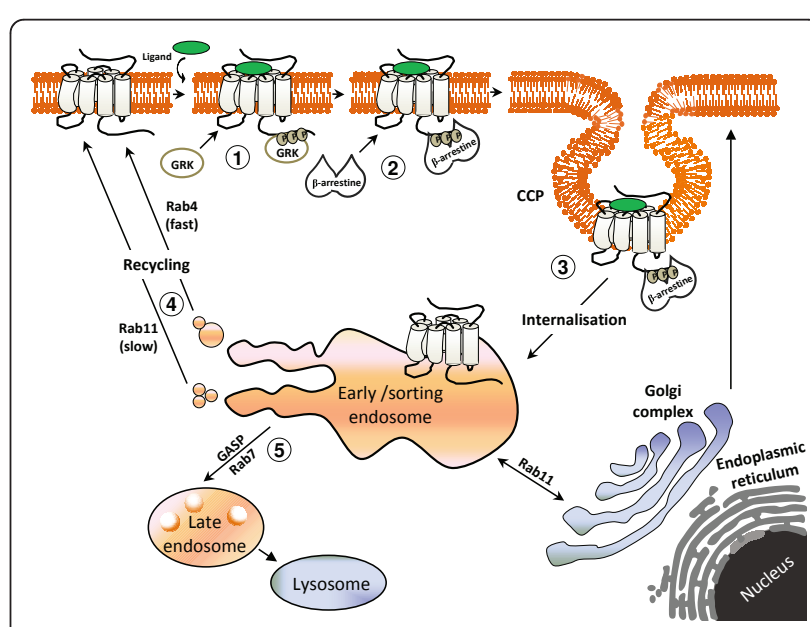

Figure 1 Steps involved in the homologous desensitization of GPCRs. According to the classical model of homologous desensitization, receptor activation by an agonist induces a series of conformational changes that trigger receptor signalling and regulation. The first of these regulatory steps is receptor phosphorylation by GRK (1). Once phosphorylated receptor affinity for $\beta$ arrestin increases, enhancing interaction between the two proteins (2) and promoting internalization (3). Internalized receptors are then directed to early/sorting endodomes where interaction with different regulatory proteins will allow them to recycle back to the membrane (4) or will directed towards degradation (5). 
for a schematic representation of the process of homologous desensitization.

\section{Regulation of opioid-mediated responses in neurons}

Studies in slices and neuronal cultures have confirmed that neuronal MORs may undergo $\beta$ arrestin-dependent internalization by full agonists like DAMGO and partial agonists like morphine [6]. Importantly, internalization following short term exposure to morphine varies across different neuronal populations. In particular, while this drug induced MOR endocytosis in striatal neurons [6] it was without effect in those of the locus coeruleus (LC) $[7,62]$, dorsal root ganglion (DRG) [8] or enteric plexus [63,64]. Such differences are not surprising since as a partial agonist internalization by morphine is expected to be influenced by the level and type of endocytic proteins expressed in each neuronal subtype. In keeping with this interpretation prolonged morphine exposure was found to enhance dynamin expression in enteric neurons, turning the agonist into an internalizing ligand [64].

Functional assays have revealed that receptor stimulation by morphine and by more efficacious ligands are all capable of inducing functional desensitization of MOR-mediated neural responses. However, the relationship between internalization and loss of signaling capacity seemed influenced by the cell type and effector considered. In particular, although short-term (20-30 min) exposure of DRG and LC neurons to internalizing ligands was associated with desensitization of channel-mediated responses, sequestration was not necessary for desensitization to take place $[7,62]$. On the other hand, interfering with sequestration of striatal MORs resulted in partial reduction of the desensitization of cyclase responses evoked by DAMGO and morphine [65]. Apart from distinct need for internalization, the mechanistic basis of desensitization seems also effector specific. In particular, N-type $\mathrm{Ca}^{+2}$ channels in DRG neurons were shown to undergo rapid desensitization that was not affected by $\beta$ arrestin2 knockout [66] but was instead mediated by a heterologous mechanism acting downstream of the receptor $[8,67,68]$. In contrast, desensitization of $G$ protein activated inward rectifier $\mathrm{K}+$ (GIRK) channels in LC neurons was homologous [62], and dependent on the combined activity of ERK1/2, G protein receptor kinase 2 (GRK2) and arrestin2 [68]. $\beta$ arrestin2 was also involved in the desensitization of cyclase responses following sustained exposure of striatal MORs to morphine and DAMGO [65]. However, in spite of its ability to trigger MOR regulation, exposure to morphine induced superactivation of the striatal cAMP cascade [69], suggesting that MOR desensitization when associated to this effector might not be enough to completely avoid cellular compensatory mechanisms.

Information concerning post-endocytic sorting of neuronal opioid receptors is quite limited. Studies in DRG neurons indicate that MORs undergo constitutive recycling which requires $\beta$ arrestin 2 -dependent internalization and trafficking through a monensin sensitive compartment $[8,66]$. Agonist stimulation of these receptors induces their colocalization with Rab4 and Rab11, indicating redistribution of DRG MORs to recycling endosomes [8]. Functional consequences of receptor recycling have been assessed in LC neurons. In these cells MOR desensitization by the endogenous agonist Met-enkephalin could be reversed upon agonist removal, resulting in complete recovery of receptor ability to evoke GIRK channel activation $[7,70]$. Interestingly, the mechanism involved in resensitization was different depending on whether desensitization was accompanied or not by internalization. Indeed, when recovery took place after internalization, resensitization was sensitive to recycling disruption by monensin [70]. In contrast, when internalization was blocked, desensitization and recovery could both take place at the membrane [7], pointing to the existence of multiple, complementary mechanisms for achieving similar regulatory control of opioid receptor signaling. The existence of multiple, complementary and cellspecific regulatory responses were not necessarily anticipated from studies in heterologous systems. They should nonetheless be carefully considered since they may point to the impossibility of developing a single, universal strategy for avoiding analgesic tolerance.

\section{In vivo regulation of opioid receptor signaling}

A critical question in understanding long term effects of opioids is whether regulatory responses described in cellular models are also triggered in vivo, and if so, what are their behavioral correlates. Insight into these issues has been obtained by assessing regulatory responses triggered by the release of endogenous opioids or following exogenous administration of different opioid receptor agonists.

\section{Opioid receptor regulation by release of endogenous opioids}

The release of endogenous opioid peptides during noxious stimulation may produce phosphorylation $[10,71]$ and internalization $[72,73]$ of central and peripheral MORs. These regulatory responses were triggered by stimuli that lead to development of persistent pain syndromes $[10,72,73]$ but not by acute noxious stimulation [74], a difference that has been attributed to 
higher receptor occupancy in the former than the latter. Consistent with this interpretation, acute painful stimuli may provoke MOR internalization if the stimulation is accompanied by administration of peptidase inhibitors that prevent rapid degradation of the released opioids [75].

From a functional point of view MOR phosphorylation following sciatic nerve ligature was correlated with desensitization of receptor ability to stimulate the G protein, development of cyclase superactivation, appearance of thermal hyperalgesia and reduced analgesic response to exogenous opioids $[10,76]$. The use of $\beta$-endorphin knock-out mice confirmed a causal link between MOR phosphorylation by this peptide and reduced responsiveness to exogenous ligands since sciatic nerve ligature in knock-out animals failed to produce both [10]. On the other hand, regulatory mechanisms triggered by endogenous opioids during the course of chronic inflammatory pain seem to have a protective effect against morphine tolerance. Indeed, depletion of opioids from white blood cells of rats that had received an intra-plantar injection of complete Freund's adjuvant (CFA) prevented MOR sequestration in primary afferents. Together with inhibition of sequestration, opioid depletion was associated with the exacerbation of cyclase superactivation and analgesic tolerance produced by intraplantar administration of morphine [72].

\section{Opioid receptor regulation by administration of opioid agonists}

As mentioned in previous sections, studies characterizing homologous desensitization of opioid receptors have prompted two alternative hypotheses in order to explain morphine tolerance. Although not necessarily compatible at other levels, both conceptualizations agree upon the fact that receptor internalization may have a protective effect against the loss of morphine's analgesic efficacy. This possibility has been directly assessed by Kim et al, 2008 [77] who used a knock-in mouse model in which wild-type MORs were replaced with a mutant receptor capable of undergoing rapid morphine-dependent sequestration [27]. What the authors report is that a 5 day treatment which almost abolished morphine analgesia in wild type mice produced no tolerance in knock-in animals [77]. The idea that MOR internalization negatively influences the development of tolerance is also supported by experiments carried out in wild type animals where the rate at which analgesic efficacy diminishes is faster for low internalizing opiates like morphine or heroin [38,77-79] than for efficiently internalizing agonists like DAMGO [80], etorphine [38,81] or methadone $[38,77]$. However, the protective effect of internalization is limited, since treatments of 7 days or longer will all eventually induce analgesic tolerance $[37,78,81,82]$ independent of the degree of internalization triggered by the agonist. Although part of this effect may be accounted for by adaptations that take place at synaptic and network levels [4], receptor adaptations are also involved since tolerance is paralleled by receptor desensitization [37,78,81-84] and down regulation $[81,85]$. Thus, if the intent is to eventually harness opioid receptor regulation as a means of prolonging opioid analgesia, it will be necessary to look beyond internalization. Characterization of the post-endocytic mechanisms whereby in vivo sequestration provides transient protection from tolerance as well as a better understanding of the causes leading to down-regulation and delayed loss of analgesic efficacy, seem essential steps for the rational development of novel, longer acting opioid analgesics.

The relationship between endocytic trafficking and analgesia is also being actively pursued for DORs. A report by Pradhan et al, 2009 [11] has recently established that a single injection of SNC-80 produced in vivo internalization of DORs which was paralleled by the development of acute analgesic tolerance. In contrast, the administration of an equianalgesic dose of AR-M1000390 produced neither internalization nor modification of subsequent analgesic responses. Based on these observations it would be tempting to speculate that acute tolerance to DOR agonists is determined by internalization. However, this interpretation is ruled out by results obtained with deltorphin II, whose administration is free of acute tolerance [86] despite its high internalization capacity [87]. The reason for the distinct tolerance potential displayed by SNC-80 and deltorphin II remains to be elucidated, but analysis of post-endocytic trafficking could shed some light onto the issue. Studies in immortalized cell lines indicate that internalization by SNC-80 is not followed by for receptor recycling [41] and in vivo experiments show that four hours after its systemic administration SNC-80-stimulated DORs remain trapped in the cytosol while analgesic tolerance is maximal [11]. On the other hand, internalization by deltorphin analogues is associated with partial recycling and resensitization of DOR signalling [88], both of which may contribute to a faster recovery of analgesic efficacy upon repeated administration of this type of ligands [86]. Based on these observations it would be interesting to determine whether preferential sorting towards the recycling path is what makes deltorphin II less prone to tolerance than SNC-80. The molecular underpinnings of agonist-specific sorting could include stabilization of agonist- 
specific conformations that distinctively interact with sorting proteins such as GASPs or $\beta$ arrestins. This reasoning is supported by reports indicating that DORs may adopt multiple active conformations [14] that are distinctively modulated by Src $[89,90]$, which is in turn involved in the modulation of DOR recycling efficacy [46].

Comparison of long-term analgesic actions evoked by internalizing and non-internalizing DOR agonists has confirmed that similar to what was observed for MORs, both types of ligands induce tolerance after repeated administration $[12,86]$. Remarkably, for some agonists desensitization of DOR-mediated signals takes place at the receptor while for others desensitization occurs at the level of the effector. For example, while tolerance by SNC-80 involves receptor desensitization AR-M1000390 leaves DORs unaffected but reduces Ca +2 channel ability to respond to stimuli [12]. An additional level of diversity that has been described in the regulation of DOR-mediated in vivo responses is that different behaviours display distinct sensitivity to tolerance. For example, while repeated AR-M1000390 administration did not modify drug ability to induce anxiolytic and psychomotor responses, it induced complete analgesic tolerance [12]. It seems unlikely that "response-specific" tolerance generated by ARM1000390's is related to its failure to internalize DORs since similar specificity has been described for internalizing ligands. In effect, sustained treatment with SNC80 led to the progressive reduction of its pro-convulsive but not antidepressant actions [91]. Similarly, sustained administration of deltorphin II resulted in the progressive reduction of antinociceptive but not antihyperalgesic actions induced by this drug [86]. The fact that sustained stimulation of the same receptor may result in different degrees of tolerance for distinct behavioural responses is highly reminiscent of observations obtained in neuronal cultures where signalling regulation was found to be cell- and effector-specific. As previously mentioned, this multiplicity of regulatory mechanisms argues against the possibility of developing a single universal means of controlling analgesic tolerance. But, on the other hand, it could provide a novel strategy for the development of more specific, longer acting analgesics. Indeed, diversity could be an advantage if it were to allow directing the pharmacological stimuli towards those receptors that are specifically involved in analgesic responses and whose cellular location and/or effector association would make them more resistant to progressive waning of signalling efficacy. In this sense it might be helpful to think of receptors not as isolated membrane proteins but as part of signalling complexes containing a combination of G proteins [14,92], effectors [93], scaffolding [94] and/or regulatory proteins whose identity is determined by the cell type and compartment in which receptors are expressed [95]. Within complexes formed in different cells, structural restrictions imposed by distinct interaction partners may force receptors and/or effectors into conformations which need not be equally recognized by regulatory proteins $[5,96]$. It would therefore be conceivable that development of ligands capable of specifically activating signalling complexes with the least capacity to trigger the regulatory mechanisms underlying tolerance could result in more prolonged analgesic actions than those of currently available opioids. A schematic representation of this idea is shown in Figure 2.

\section{Concluding remarks}

Initial mechanistic hypotheses concerning the molecular bases of opioid tolerance focused on homologous desensitization, viewing internalization as a key protective step for maintaining analgesic efficacy. Neuronal and in vivo studies tend to partially confirm this view, but also point to a greater level of complexity where post-endocytic sorting and multiplicity of regulatory mechanisms argue against a simple, universal strategy for reducing tolerance. Embracing this diversity through the production of biased ligands capable of favouring recycling or of directing pharmacological stimuli towards signalling complexes that are more resistant to functional desensitization could constitute novel strategies for rational design of longer acting opioid analgesics.

\section{List of abbreviations}

(SNC-80): ((+)-4-[(alpha R)-alpha-((2S,5R)-4-allyl-2,5-dimethyl-1-piperazinyl)-3methoxybenzyl]-N, N-diethyl-benzamide); (CFA): complete Freund's adjuvant; (DAMGO): [D-Ala(2), N-Me-Phe(4), Gly(5)-ol]-enkephalin; (DORs): delta opioid receptors; (DRG): dorsal root ganglion; (ERK1/2): extracellular signalregulated kinases; (GASP): G protein coupled receptor associated sorting protein; (GIRK): G protein activated inward rectifier K+; (GPCRs): G protein-coupled receptors; (LC): locus coeruleus; (MORs): mu opioid receptors; (AR-M1000390): N, NDiethyl- 4-(phenylpiperidin-4-ylidenemethyl) benzamide.

\section{Acknowledgements}

KN received a studentship from Ste-Justine Hospital research center. Research was funded by NSERC grant 311997 and CIHR MOP 79432 to GP. One of a series of four reviews on $G$ protein-coupled receptors published in memory of Hubert H. M. Van Tol (1959-2006), formerly Head of Molecular Biology at the Centre for Addiction and Mental Health, and a Professor in the Departments of Psychiatry and Pharmacology at the University of Toronto. Hubert's contributions to $\mathrm{G}$ protein-coupled receptor research and neuroscience are numerous and are best remembered by his central role in the cloning of the dopamine receptor family. His many achievements were recognized through awards such as the John Dewan award, The Prix Galien, and the Joey \& Toby Tanenbaum Distinguished Scientist Award for Schizophrenia Research.

\section{Author details}

1Département de Pharmacologie, Faculté de Médecine, Université de Montréal, Canada. ²Département de Psychiatrie, Faculté de Médecine, 
a)

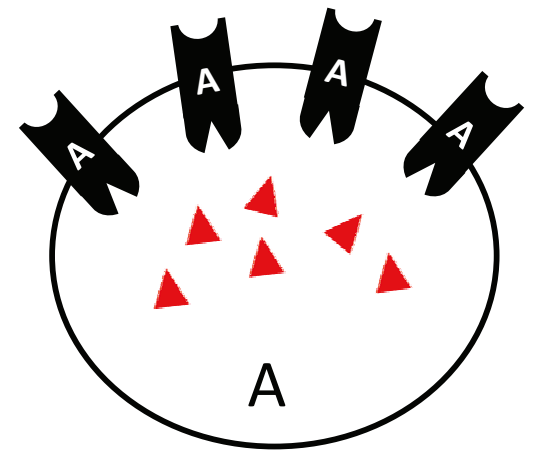

Tolerance $\Longrightarrow$

b)

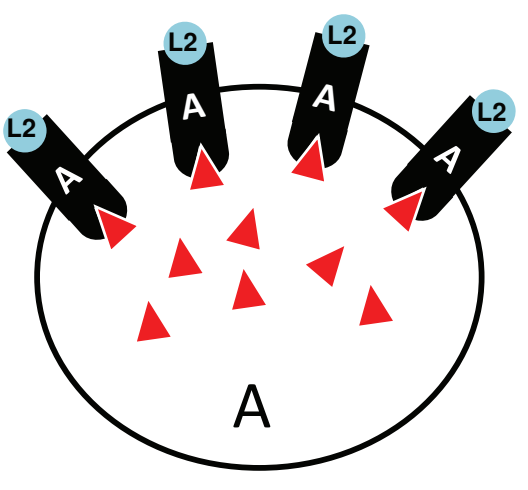

Tolerance

c)

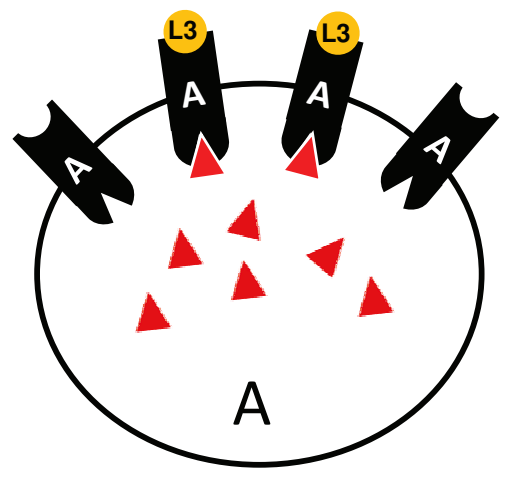

Tolerance
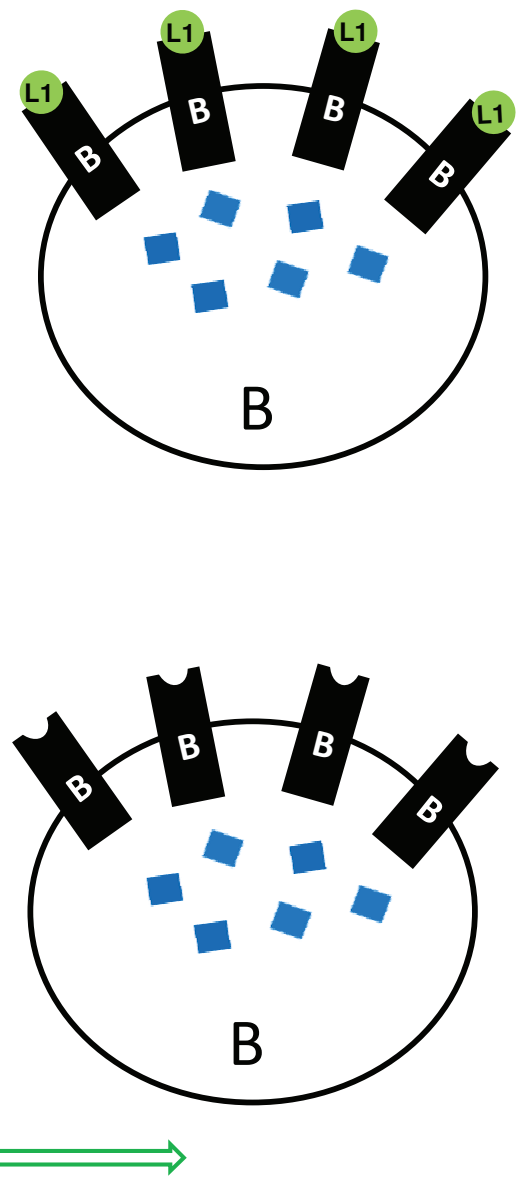
Université de Montréal, Montréal, Québec, H3C 3J7, Canada. ${ }^{3}$ Centre de recherche du CHU Sainte-Justine, 3175, Côte-Sainte-Catherine Montréal, Québec, H3T 1C5, Canada.

\section{Authors' contributions}

KN conducted reference research, contributed discussion and figure concerning signalling complexes. GP conducted reference research and wrote the review. All authors read and approved the final manuscript.

\section{Competing interests}

The authors declare that they have no competing interests.

Received: 28 March 2011 Accepted: 13 June 2011

Published: 13 June 2011

\section{References}

1. Gainetdinov RR, Premont RT, Bohn LM, Lefkowitz RJ, Caron MG: Desensitization of $\mathrm{g}$ protein-coupled receptors and neuronal functions. Annu Rev Neurosci 2004, 27:107-144.

2. Martini $L$, Whistler JL: The role of mu opioid receptor desensitization and endocytosis in morphine tolerance and dependence. Curr Opin Neurobiol 2007, 17(5):556-564.

3. Ko SW, Wu LJ, Shum F, Quan J, Zhuo M: Cingulate nmda nr2b receptors contribute to morphine-induced analgesic tolerance. $\mathrm{Mol}$ Brain 2008, 1:2.

4. Christie MJ: Cellular neuroadaptations to chronic opioids: Tolerance, withdrawal and addiction. Br J Pharmacol 2008, 154(2):384-396.

5. Pineyro G, Archer-Lahlou E: Ligand-specific receptor states: Implications for opiate receptor signalling and regulation. Cell Signal 2007, 19(1):8-19.

6. Haberstock-Debic H, Kim KA, Yu YJ, von Zastrow M: Morphine promotes rapid, arrestin-dependent endocytosis of mu-opioid receptors in striatal neurons. J Neurosci 2005, 25(34):7847-7857.

7. Arttamangkul S, Torrecilla M, Kobayashi K, Okano H, Williams JT: Separation of mu-opioid receptor desensitization and internalization: Endogenous receptors in primary neuronal cultures. J Neurosci 2006, 26(15):4118-4125.

8. Walwyn WM, Wei W, Xie CW, Chiu K, Kieffer BL, Evans CJ, Maidment NT: Mu opioid receptor-effector coupling and trafficking in dorsal root ganglia neurons. Neuroscience 2006, 142(2):493-503.

9. Trafton JA, Basbaum Al: [d-ala2, n-mephe4, gly-ol5]enkephalin-induced internalization of the micro opioid receptor in the spinal cord of morphine tolerant rats. Neuroscience 2004, 125(3):541-543.

10. Petraschka M, Li S, Gilbert TL, Westenbroek RE, Bruchas MR, Schreiber S, Lowe J, Low MJ, Pintar JE, Chavkin C: The absence of endogenous betaendorphin selectively blocks phosphorylation and desensitization of mu opioid receptors following partial sciatic nerve ligation. Neuroscience 2007, 146(4):1795-1807.

11. Pradhan AA, Becker JA, Scherrer G, Tryoen-Toth P, Filliol D, Matifas A, Massotte D, Gaveriaux-Ruff C, Kieffer BL: In vivo delta opioid receptor internalization controls behavioral effects of agonists. PLoS One 2009, 4(5):e5425.

12. Pradhan AA, Walwyn W, Nozaki C, Filliol D, Erbs E, Matifas A, Evans C, Kieffer BL: Ligand-directed trafficking of the delta-opioid receptor in vivo: Two paths toward analgesic tolerance. J Neurosci 2010, 30(49):16459-16468.

13. Gupta A, Decaillot FM, Gomes I, Tkalych O, Heimann AS, Ferro ES, Devi LA: Conformation state-sensitive antibodies to g-protein-coupled receptors. J Biol Chem 2007, 282(8):5116-5124.

14. Audet N, Gales C, Archer-Lahlou E, Vallieres M, Schiller PW, Bouvier M, Pineyro G: Bioluminescence resonance energy transfer assays reveal ligand-specific conformational changes within preformed signaling complexes containing delta-opioid receptors and heterotrimeric $\mathrm{g}$ proteins. J Biol Chem 2008, 283(22):15078-15088.

15. Kovoor A, Celver JP, Wu A, Chavkin C: Agonist induced homologous desensitization of mu-opioid receptors mediated by $\mathrm{g}$ protein-coupled receptor kinases is dependent on agonist efficacy. Mol Pharmacol 1998, 54(4):704-711.

16. Marie N, Aguila B, Hasbi A, Davis A, Jauzac P, Allouche S: Different kinases desensitize the human delta-opioid receptor (hdop-r) in the neuroblastoma cell line sk-n-be upon peptidic and alkaloid agonists. Cell Signal 2008, 20(6):1209-1220.
17. Zhang X, Wang F, Chen X, Li J, Xiang B, Zhang YQ, Li BM, Ma L: Betaarrestin 1 and beta-arrestin 2 are differentially required for phosphorylation-dependent and -independent internalization of deltaopioid receptors. J Neurochem 2005, 95(1):169-178.

18. Groer CE, Tidgewell K, Moyer RA, Harding WW, Rothman RB, Prisinzano TE, Bohn LM: An opioid agonist that does not induce micro-opioid receptorarrestin interactions or receptor internalization. Mol Pharmacol 2007, 71(2):549-557.

19. Qiu Y, Loh HH, Law PY: Phosphorylation of the delta-opioid receptor regulates its beta-arrestins selectivity and subsequent receptor internalization and adenylyl cyclase desensitization. J Biol Chem 2007, 282(31):22315-22323.

20. Celver JP, Lowe J, Kovoor A, Gurevich W, Chavkin C: Threonine 180 is required for g-protein-coupled receptor kinase 3-and beta-arrestin 2-mediated desensitization of the mu-opioid receptor in xenopus oocytes. J Biol Chem 2001, 276(7):4894-4900.

21. Laporte SA, Oakley RH, Holt JA, Barak LS, Caron MG: The interaction of beta-arrestin with the ap-2 adaptor is required for the clustering of beta 2-adrenergic receptor into clathrin-coated pits. J Biol Chem 2000, 275(30):23120-23126.

22. Laporte SA, Miller WE, Kim KM, Caron MG: Beta-arrestin/ap-2 interaction in $\mathrm{g}$ protein-coupled receptor internalization: Identification of a betaarrestin binging site in beta 2-adaptin. J Biol Chem 2002, 277(11):9247-9254.

23. Whistler JL, Chuang HH, Chu P, Jan LY, von Zastrow M: Functional dissociation of mu opioid receptor signaling and endocytosis: Implications for the biology of opiate tolerance and addiction. Neuron 1999, 23(4):737-746.

24. Alvarez VA, Arttamangkul S, Dang V, Salem A, Whistler JL, Von Zastrow M, Grandy DK, Williams JT: Mu-opioid receptors: Ligand-dependent activation of potassium conductance, desensitization, and internalization. J Neurosci 2002, 22(13):5769-5776.

25. Keith DE, Murray SR, Zaki PA, Chu PC, Lissin DV, Kang L, Evans CJ, von Zastrow M: Morphine activates opioid receptors without causing their rapid internalization. J Biol Chem 1996, 271(32):19021-19024.

26. Aguila B, Coulbault L, Boulouard M, Leveille F, Davis A, Toth G, Borsodi A, Balboni G, Salvadori S, Jauzac P, Allouche S: In vitro and in vivo pharmacological profile of ufp-512, a novel selective delta-opioid receptor agonist; correlations between desensitization and tolerance. $\mathrm{Br}$ J Pharmacol 2007, 152(8):1312-1324.

27. Finn AK, Whistler JL: Endocytosis of the mu opioid receptor reduces tolerance and a cellular hallmark of opiate withdrawal. Neuron 2001, 32(5):829-839.

28. Eisinger DA, Ammer H, Schulz R: Chronic morphine treatment inhibits opioid receptor desensitization and internalization. J Neurosci 2002, 22(23):10192-10200.

29. Connor M, Osborne PB, Christie MJ: Mu-opioid receptor desensitization: Is morphine different? Br J Pharmacol 2004, 143(6):685-696.

30. Grecksch G, Bartzsch K, Widera A, Becker A, Hollt V, Koch T: Development of tolerance and sensitization to different opioid agonists in rats. Psychopharmacology (Berl) 2006, 186(2):177-184.

31. Pawar M, Kumar P, Sunkaraneni S, Sirohi S, Walker EA, Yoburn BC: Opioid agonist efficacy predicts the magnitude of tolerance and the regulation of mu-opioid receptors and dynamin-2. Eur J Pharmacol 2007, 563(13):92-101.

32. Borgland SL, Connor M, Osborne PB, Furness JB, Christie MJ: Opioid agonists have different efficacy profiles for $\mathrm{g}$ protein activation, rapid desensitization, and endocytosis of mu-opioid receptors. J Biol Chem 2003, 278(21):18776-18784

33. Dang VC, Williams JT: Morphine-induced mu-opioid receptor desensitization. Mol Pharmacol 2005, 68(4):1127-1132.

34. McPherson J, Rivero G, Baptist M, Llorente J, Al-Sabah S, Krasel C, Dewey WL, Bailey CP, Rosethorne EM, Charlton SJ, Henderson G, et al: Muopioid receptors: Correlation of agonist efficacy for signalling with ability to activate internalization. Mol Pharmacol 2010, 78(4):756-766.

35. Molinari P, Vezzi V, Sbraccia M, Gro C, Riitano D, Ambrosio C, Casella I, Costa T: Morphine-like opiates selectively antagonize receptor-arrestin interactions. J Biol Chem 2010, 285(17):12522-12535.

36. Navratilova E, Eaton MC, Stropova D, Varga EV, Vanderah TW, Roeske WR, Yamamura HI: Morphine promotes phosphorylation of the human deltaopioid receptor at serine 363. Eur J Pharmacol 2005, 519(3):212-214. 
37. Bohn LM, Lefkowitz RJ, Gainetdinov RR, Peppel K, Caron MG, Lin FT: Enhanced morphine analgesia in mice lacking beta-arrestin 2. Science 1999, 286(5449):2495-2498.

38. Bohn LM, Dykstra LA, Lefkowitz RJ, Caron MG, Barak LS: Relative opioid efficacy is determined by the complements of the $\mathrm{g}$ protein-coupled receptor desensitization machinery. Mol Pharmacol 2004, 66(1):106-112.

39. Koch T, Widera A, Bartzsch K, Schulz S, Brandenburg LO, Wundrack N, Beyer A, Grecksch G, Hollt V: Receptor endocytosis counteracts the development of opioid tolerance. Mol Pharmacol 2005, 67(1):280-287.

40. Marie N, Landemore G, Debout C, Jauzac P, Allouche S: Pharmacological characterization of ar-m1000390 at human delta opioid receptors. Life Sci 2003, 73(13):1691-1704

41. Lecoq I, Marie N, Jauzac P, Allouche S: Different regulation of human delta-opioid receptors by snc-80 [(+)-4-[(alphar)-alpha-((2s,5r)-4-allyl2,5-dimethyl-1-piperazinyl)-3-meth oxybenzyl]-n, n-diethylbenzamide] and endogenous enkephalins. J Pharmacol Exp Ther 2004, 310(2):666-677.

42. Gomes BA, Shen J, Stafford K, Patel M, Yoburn BC: Mu-opioid receptor down-regulation and tolerance are not equally dependent upon g-protein signaling. Pharmacol Biochem Behav 2002, 72(1-2):273-278.

43. Law PY, Erickson LJ, El-Kouhen R, Dicker L, Solberg J, Wang W, Miller E, Burd $\mathrm{AL}$, Loh $\mathrm{HH}$ : Receptor density and recycling affect the rate of agonist-induced desensitization of mu-opioid receptor. Mol Pharmacol 2000, 58(2):388-398.

44. Trapaidze N, Gomes I, Bansinath M, Devi LA: Recycling and resensitization of delta opioid receptors. DNA Cell Biol 2000, 19(4):195-204.

45. Hasbi A, Allouche S, Sichel F, Stanasila L, Massotte D, Landemore G, Polastron J, Jauzac P: Internalization and recycling of delta-opioid receptor are dependent on a phosphorylation-dephosphorylation mechanism. J Pharmacol Exp Ther 2000, 293(1):237-247.

46. Archer-Lahlou E, Audet N, Amraei MG, Huard K, Paquin-Gobeil M, Pineyro G: Src promotes delta opioid receptor (dor) desensitization by interfering with receptor recycling. J Cell Mol Med 2009, 13(1):147-163.

47. Whistler JL, Enquist J, Marley A, Fong J, Gladher F, Tsuruda P, Murray SR, Von Zastrow M: Modulation of postendocytic sorting of g proteincoupled receptors. Science 2002, 297(5581):615-620.

48. Hislop JN, Henry AG, Marchese A, von Zastrow M: Ubiquitination regulates proteolytic processing of $\mathrm{g}$ protein-coupled receptors after their sorting to lysosomes. J Biol Chem 2009, 284(29):19361-19370.

49. Marchese A, Paing MM, Temple BR, Trejo J: G protein-coupled receptor sorting to endosomes and lysosomes. Annu Rev Pharmacol Toxicol 2008, 48:601-629.

50. He SQ, Zhang ZN, Guan JS, Liu HR, Zhao B, Wang HB, Li Q, Yang H, Luo J, Li ZY, Wang Q, et al: Facilitation of mu-opioid receptor activity by preventing delta-opioid receptor-mediated codegradation. Neuron 2011, 69(1):120-131.

51. Chaturvedi K, Bandari P, Chinen N, Howells RD: Proteasome involvement in agonist-induced down-regulation of mu and delta opioid receptors. J Biol Chem 2001, 276(15):12345-12355

52. Tsao Pl, von Zastrow M: Type-specific sorting of g protein-coupled receptors after endocytosis. J Biol Chem 2000, 275(15):11130-11140.

53. Ko JL, Arvidsson U, Williams FG, Law PY, Elde R, Loh HH: Visualization of time-dependent redistribution of delta-opioid receptors in neuronal cells during prolonged agonist exposure. Brain Res Mol Brain Res 1999, 69(2):171-185.

54. Henry AG, White IJ, Marsh M, von Zastrow M, Hislop JN: The role of ubiquitination in lysosomal trafficking of delta-opioid receptors. Traffic 2011, 12(2):170-184.

55. Heydorn A, Sondergaard BP, Ersboll B, Holst B, Nielsen FC, Haft CR, Whistler J, Schwartz TW: A library of 7tm receptor c-terminal tails. Interactions with the proposed post-endocytic sorting proteins ermbinding phosphoprotein 50 (ebp50), n-ethylmaleimide-sensitive factor (nsf), sorting nexin 1 (snx1), and g protein-coupled receptor-associated sorting protein (gasp). J Biol Chem 2004, 279(52):54291-54303.

56. Tanowitz $M$, von Zastrow M: A novel endocytic recycling signal that distinguishes the membrane trafficking of naturally occurring opioid receptors. J Biol Chem 2003, 278(46):45978-45986.

57. Koch T, Schulz S, Schroder H, Wolf R, Raulf E, Hollt V: Carboxyl-terminal splicing of the rat mu opioid receptor modulates agonist-mediated internalization and receptor resensitization. J Biol Chem 1998, 273(22):13652-13657
58. Koch T, Schulz S, Pfeiffer M, Klutzny M, Schroder H, Kahl E, Hollt V: Cterminal splice variants of the mouse mu-opioid receptor differ in morphine-induced internalization and receptor resensitization. J Biol Chem 2001, 276(33):31408-31414.

59. Wu DF, Koch T, Liang YJ, Stumm R, Schulz S, Schroder H, Hollt V: Membrane glycoprotein $\mathrm{m} 6 \mathrm{a}$ interacts with the micro-opioid receptor and facilitates receptor endocytosis and recycling. J Biol Chem 2007, 282(30):22239-22247.

60. Wang F, Chen X, Zhang X, Ma L: Phosphorylation state of mu-opioid receptor determines the alternative recycling of receptor via rab4 or rab11 pathway. Mol Endocrinol 2008, 22(8):1881-1892.

61. Zhang X, Wang F, Chen X, Chen Y, Ma L: Post-endocytic fates of deltaopioid receptor are regulated by grk2-mediated receptor phosphorylation and distinct beta-arrestin isoforms. J Neurochem 2008, 106(2):781-792.

62. Arttamangkul S, Quillinan N, Low MJ, von Zastrow M, Pintar J, Williams JT: Differential activation and trafficking of micro-opioid receptors in brain slices. Mol Pharmacol 2008, 74(4):972-979.

63. Minnis JG, Patierno S, Kohlmeier SE, Brecha NC, Tonini M, Sternini C: Ligand-induced mu opioid receptor endocytosis and recycling in enteric neurons. Neuroscience 2003, 119(1):33-42.

64. Patierno S, Anselmi L, Jaramillo I, Scott D, Garcia R, Sternini C: Morphine induces mu opioid receptor endocytosis in guinea pig enteric neurons following prolonged receptor activation. Gastroenterology 2011, 140(2):618-626.

65. Yu YJ, Arttamangkul S, Evans CJ, Williams JT, von Zastrow M: Neurokinin 1 receptors regulate morphine-induced endocytosis and desensitization of mu-opioid receptors in cns neurons. J Neurosci 2009, 29(1):222-233.

66. Walwyn W, Evans CJ, Hales TG: Beta-arrestin2 and c-src regulate the constitutive activity and recycling of mu opioid receptors in dorsal root ganglion neurons. J Neurosci 2007, 27(19):5092-5104.

67. Nomura K, Reuveny E, Narahashi T: Opioid inhibition and desensitization of calcium channel currents in rat dorsal root ganglion neurons. J Pharmacol Exp Ther 1994, 270(2):466-474.

68. Dang VC, Napier IA, Christie MJ: Two distinct mechanisms mediate acute mu-opioid receptor desensitization in native neurons. J Neurosci 2009, 29(10):3322-3327.

69. Van Vliet BJ, De Vries TJ, Wardeh G, Mulder AH, Schoffelmeer AN: Muopioid receptor-regulated adenylate cyclase activity in primary cultures of rat striatal neurons upon chronic morphine exposure. Eur J Pharmacol 1991, 208(2):105-111.

70. Dang VC, Williams JT: Chronic morphine treatment reduces recovery from opioid desensitization. J Neurosci 2004, 24(35):7699-7706.

71. Narita M, Kuzumaki N, Suzuki M, Oe K, Yamazaki M, Yajima Y, Suzuki T: Increased phosphorylated-mu-opioid receptor immunoreactivity in the mouse spinal cord following sciatic nerve ligation. Neurosci Lett 2004, 354(2):148-152.

72. Zollner C, Mousa SA, Fischer O, Rittner HL, Shaqura M, Brack A, Shakibaei M, Binder W, Urban F, Stein C, Schafer M: Chronic morphine use does not induce peripheral tolerance in a rat model of inflammatory pain. $J$ Clin Invest 2008, 118(3):1065-1073.

73. Chen W, Marvizon JC: Acute inflammation induces segmental, bilateral, supraspinally mediated opioid release in the rat spinal cord, as measured by mu-opioid receptor internalization. Neuroscience 2009, 161(1):157-172.

74. Trafton JA, Abbadie C, Marek K, Basbaum Al: Postsynaptic signaling via the [mu]-opioid receptor: Responses of dorsal horn neurons to exogenous opioids and noxious stimulation. J Neurosci 2000, 20(23):8578-8584.

75. Lao L, Song B, Chen W, Marvizon JC: Noxious mechanical stimulation evokes the segmental release of opioid peptides that induce mu-opioid receptor internalization in the presence of peptidase inhibitors. Brain Res 2008, 1197:85-93.

76. Liu JG, Rovnaghi CR, Garg S, Anand KJ: Opioid receptor desensitization contributes to thermal hyperalgesia in infant rats. Eur J Pharmacol 2004 491(2-3):127-136.

77. Kim JA, Bartlett S, He L, Nielsen CK, Chang AM, Kharazia V, Waldhoer M, Ou CJ, Taylor S, Ferwerda M, Cado D, et al: Morphine-induced receptor endocytosis in a novel knockin mouse reduces tolerance and dependence. Curr Biol 2008, 18(2):129-135. 
78. Bohn LM, Gainetdinov RR, Lin FT, Lefkowitz RJ, Caron MG: Mu-opioid receptor desensitization by beta-arrestin-2 determines morphine tolerance but not dependence. Nature 2000, 408(6813):720-723.

79. Bohn LM, Lefkowitz RJ, Caron MG: Differential mechanisms of morphine antinociceptive tolerance revealed in (beta)arrestin-2 knock-out mice. J Neurosci 2002, 22(23):10494-10500.

80. Narita M, Suzuki M, Niikura K, Nakamura A, Miyatake M, Yajima Y, Suzuki T: Mu-opioid receptor internalization-dependent and -independent mechanisms of the development of tolerance to mu-opioid receptor agonists: Comparison between etorphine and morphine. Neuroscience 2006, 138(2):609-619.

81. Patel MB, Patel CN, Rajashekara V, Yoburn BC: Opioid agonists differentially regulate mu-opioid receptors and trafficking proteins in vivo. $\mathrm{Mol}$ Pharmacol 2002, 62(6):1464-1470.

82. Narita M, Yoshizawa K, Aoki K, Takagi M, Miyatake M, Suzuki T: A putative sigma1 receptor antagonist ne-100 attenuates the discriminative stimulus effects of ketamine in rats. Addict Biol 2001, 6(4):373-376.

83. Sim L, Selley DE, Dworkin SI, Childers SR: Effects of chronic morphine administration on mu opioid receptor-stimulated [35s]gtpgammas autoradiography in rat brain. J Neurosci 1996, 16(8):2684-2692.

84. Maher CE, Martin TJ, Childers SR: Mechanisms of mu opioid receptor/gprotein desensitization in brain by chronic heroin administration. Life Sci 2005, 77(10):1140-1154.

85. Sirohi S, Dighe SV, Walker EA, Yoburn BC: The analgesic efficacy of fentanyl: Relationship to tolerance and mu-opioid receptor regulation. Pharmacol Biochem Behav 2008, 91(1):115-120.

86. Beaudry H, Proteau-Gagne A, Li S, Dory Y, Chavkin C, Gendron L: Differential noxious and motor tolerance of chronic delta opioid receptor agonists in rodents. Neuroscience 2009, 161(2):381-391.

87. Bradbury FA, Zelnik JC, Traynor JR: G protein independent phosphorylation and internalization of the delta-opioid receptor. J Neurochem 2009, 109(5):1526-1535.

88. Marie N, Lecoq I, Jauzac P, Allouche S: Differential sorting of human deltaopioid receptors after internalization by peptide and alkaloid agonists. J Biol Chem 2003, 278(25):22795-22804.

89. Audet N, Paquin-Gobeil M, Landry-Paquet O, Schiller PW, Pineyro G Internalization and src activity regulate the time course of erk activation by delta opioid receptor ligands. J Biol Chem 2005, 280(9):7808-7816.

90. Hong MH, Xu C, Wang YJ, Ji JL, Tao YM, Xu XJ, Chen J, Xie X, Chi ZQ Liu JG: Role of src in ligand-specific regulation of delta-opioid receptor desensitization and internalization. J Neurochem 2009, 108(1):102-114.

91. Jutkiewicz EM, Kaminsky ST, Rice KC, Traynor JR, Woods JH: Differential behavioral tolerance to the delta-opioid agonist snc80 ([(+)-4-[(alphar)alpha-[(2s,5r)-2,5-dimethyl-4-(2-propenyl)-1-piperazinyl ]-(3methoxyphenyl)methyl]-n, $\mathrm{n}$-diethylbenzamide) in sprague-dawley rats. J Pharmacol Exp Ther 2005, 315(1):414-422.

92. Gales C, Rebois RV, Hogue M, Trieu P, Breit A, Hebert TE, Bouvier M: Realtime monitoring of receptor and g-protein interactions in living cells. Nat Methods 2005, 2(3):177-184.

93. Dupre DJ, Hebert TE: Biosynthesis and trafficking of seven transmembrane receptor signalling complexes. Cell Signal 2006, 18(10):1549-1559.

94. Kreienkamp HJ: Organisation of g-protein-coupled receptor signalling complexes by scaffolding proteins. Curr Opin Pharmacol 2002, 2(5):581-586.

95. Ostrom RS, Insel PA: The evolving role of lipid rafts and caveolae in $\mathrm{g}$ protein-coupled receptor signaling: Implications for molecular pharmacology. Br J Pharmacol 2004, 143(2):235-245.

96. Pineyro G: Membrane signalling complexes: Implications for development of functionally selective ligands modulating heptahelical receptor signalling. Cell Signal 2009, 21(2):179-185.

doi:10.1186/1756-6606-4-25

Cite this article as: Nagi and Piñeyro: Regulation of opioid receptor signalling: Implications for the development of analgesic tolerance. Molecular Brain 2011 4:25

\section{Submit your next manuscript to BioMed Central and take full advantage of:}

- Convenient online submission

- Thorough peer review

- No space constraints or color figure charges

- Immediate publication on acceptance

- Inclusion in PubMed, CAS, Scopus and Google Scholar

- Research which is freely available for redistribution

Submit your manuscript at www.biomedcentral.com/submit 